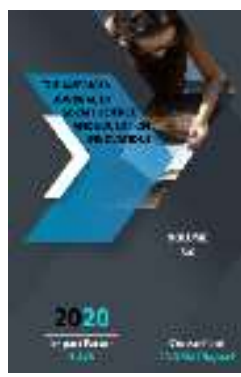

\title{
Activities Of Sheikh And Servants In Pilgrimages
}

\author{
Sanabar Djuraeva \\ Candidate Of Historical Sciences, Doctoral Student (Dsc) National University Of Uzbekistan
}

Journal Website: http://usajournalshub.c om/index,php/tajssei

Copyright: Original content from this work may be used under the terms of the creative commons attributes 4.0 licence.

\section{ABSTRACT}

This article contains scientific information about the role of the sheikh and the workers in the Middle Ages, associated with the mysticism of Mawlanunnahr, and about the distribution of the Foundation's assets to those who serve in the Middle Ages.

\section{KEYWORDS}

Sufism, scholars, shrine, sheikh, junkers, takya, property, waqf.

\section{INTRODUCTION}

The territory of Uzbekistan, which has a special place in the history of world civilization, is famous in the Islamic world for its Imam Bukhari, Abu Isa Termizi, Hakim Termizi, Najmiddin Kubro, Abdukholiq Gijduvani, Bahauddin Naqshbandi, Sayfiddin Bokharzi, Imam Moturidi, Burhaniddin Marginoni and others. One of the urgent tasks today is to study the history of the shrines of our ancestors, their role in our material and spiritual life, the activities of those who serve there, to create conditions for pilgrims, to attract local and foreign tourists to the shrines. 
In the Middle Ages, due to the frequent visits of the locals of Movarounnahr to the shrines, sheikhs were appointed to these shrines by the ruling dynasty, governors and principalities. Until the end of the 19th century, they served the pilgrims.

"Sheikh" is the name given to scholars, Islamic leaders and faqihs in countries where Islam is widespread. Later, the pirs, eshons, and officials of the holy places of the Sufi order were also called "Sheikh". In Central Asia, the "sheikh" was often used in reference to the clergy who received alms and vows in sacred tombs and shrines [6:562].

\section{THE MAIN RESULTS AND FINDINGS}

In the explanatory dictionary of the Uzbek language, "Sheikh" is interpreted as "the clerk of the shrines, shrines, shrines, saints, the priest who accepts offerings to the path of God" [9: 392].

But this comment about the "Sheikh" is not enough. The tomb sheikh played an important role not only as a recipient of the vows, but also as a person who maintained the status of the tomb, continuing the ancient traditions there.

The ownership of the holy shrines and the position of sheikh in them have not lost their importance until recently, and in achieving this authority, the right of sheikh is divided into the following categories:
a) A group of sayyids;
b) A group of owners;
c) A group of descendants of the Eshans, who are representatives of the mystical sect;
d) A group of madrasah teachers, mahdums who served under the Sufi pirs;

e) A group of ordinary families who gained the right of sheikh due to their service in cemeteries [1:60].

The first person known by the nickname "Sufi" was Abu Hashim Sufi (died 767) from Kufa. The first takya in the history of Sufism, the khanaqah, was built by a Christian Amir in the city of Royal for Abu Hashim. [8:49] In Sufis, takya and khanaqahs were built on their graves [2: 100].

There were chillahanas near the takya khanqahs, where the Sufis sat in the chilla for forty days, that is, they were cut off from the outside world and prayed. The tombs in Takya or Khanaqah became a place of pilgrimage for the Sufis, who recited the Qur'an in honor of the Sufis who lay here, and considered this place a sacred shrine or a sacred place.

The Moroccan traveler Ibn Battuta's Travelogue provides valuable information on the medieval history of Central Asia. During his trip to Central Asia, he said, "When Sheikh Najmiddin Kubro, a Sufi, went to the zoviya (khanaqah) in front of his tomb, food was being prepared for the pilgrims. At that time, the sheikh of this khanaqah was Sayfiddin ibn Asaba. Jalaliddin Samarkandi, one of the greatest ascetics in the neighboring khanate, said that he was a sheikh, and that there were waqf properties (fields, gardens) reserved for the priests serving in the pilgrimages. [5:49]

A waqf is property that has been allocated by the state or Muslims in Muslim countries for religious needs or charitable causes [6: 122].

Ibn Battuta visited the tomb of Sayfiddin Bukhari in Bukhara. He wrote: "The tomb at the tomb of Sayfiddin Bokharzi is very large, and it is planned to feed the pilgrims at the expense of the waqf property allocated to it. Yahya 
Bokharzi (1335-1336), one of the descendants of Sheikh Zayiya Sayfiddin Bokharzi, went on a holy pilgrimage "[5:50].

The tourist said, "Old Termez was built on the shores of Ceyhan. After Genghis destroyed it, the new city was built two miles from the river. We landed there on the shores of Sheikh Azizon, one of the most revered sheikhs who owns large tracts of land and gardens. The sheikh used his wealth to feed the pilgrims. "[5:77] According to Ibn Battuta, Sheikh Azizon's shrine is now the shrine of Sultan Saodat in Termez district of Surkhandarya region, and is a complex of mausoleums of Termez Sayyids of Hussein dynasty, the grandson of the Prophet Muhammad (SAAS).

At that time, Alo-ul-Mulk Khudovandzoda, one of the Sayyids of Termez, was the deputy of Termez. Sayyids of Termez ruled over this mausoleum during the XI-XIX centuries [4:89].

Amir Temur in his "Regulations" said: Let the poor and the needy, the helpless and the blind receive alimony. Teachers and sheikhs should be assigned their daily salaries.

Let the saints allocate funds from the foundation for the tombs and mausoleums of the clergy. Let them provide the land with carpet, food, and a lamp. First of all, let the Amir al-Mu'minin, the king of the brave, Ali ibn Abu Talib, grant him the blessings and blessings of Allah, and grant him Najaf and Hula as waqfs in order to preserve his holy tombs. Also, for the tombs and graves of the sheikhs of Turan and Iran, each of them should be given a separate name-waqf." [3: 133-134].

This means that the sheikhdom of the shrine is a unique series of Sufi saints, and the sheikhdom has been passed down from generation to generation. The shrine and its worshipers are provided with waqf property.

Regarding the mausoleum sheikhs, B.Kh. Karmysheva said: "As for the people in the mausoleums, their place and income in the society were connected with the popularity of the shrines they guarded and the benefits of its foundation. Ordinary sheikhs and members of their families were responsible for providing places for pilgrims to spend the night, preparing firewood for cooking utensils and meat of sacrificial animals, and cleaning the grave, including toilets and cooking for religious ceremonies, the altar, and the mosque. [7: 101].

It is possible to draw such a conclusion from the above. The right to be a sheikh in each shrine was initially determined by the descendants of his previous sheikhs. The position of the shrine also depended on the status of the scholar, saint, or sheikh of the shrine lying there.

The place and position of the sheikhs in the holy shrines can be divided into the following categories:

a) great sheikhs. The list of senior sheikhs included sheikhs who had the right to own the keys to the holy shrines. Such sheikhs had their own room in the shrines and could only enter the tomb with their permission. The great sheikhs also had the ability to cure a variety of sick people, including the insane.

b) Small sheikhs. The number of such sheikhs in the holy shrines alone was sometimes more than ten, and they were engaged in secondary affairs. They are gathered around trees, springs, or sacred stones around the tomb. The younger sheikhs 
were also engaged in entertaining the pilgrims and preserving from evil. Due to the large number of such sheikhs, the right to be a sheikh in shrines is determined by certain two or three days of the week. The main task of such sheikhs was to bless the pilgrims.

The sheikhs at the shrines are further divided into two groups.

a) Family sheikhs: double sheikhs, brother sheikhs, sister sheikhs, father and son sheikhs, mother and daughter sheikhs. The elder of such family sheikhs has always been the chief sheikh of the shrine.

b) Alone sheikhs. The authority of such sheikhs was less than that of family sheikhs.

There are the following requirements for being a sheikh: the ability to heal, the permission of the previous sheikh of the tomb, the person's initial religious knowledge (such as praying, knowledge of Qur'an verses), the ability to communicate with pilgrims.

During the years of independence, the preservation of material and spiritual monuments, the restoration of religious and national values have risen to the level of state policy. PD-4947 of the President of the Republic of Uzbekistan dated February 7, 2017 "On action strategy for further development of the Republic of Uzbekistan", PD -5328 of February 3, 2018 "On additional measures to create favorable conditions for the development of tourism potential of the Republic of Uzbekistan" On the basis of the Decree of the Cabinet of Ministers of the Republic of Uzbekistan №. 9709-5 dated April 16, 2018 "On measures to radically improve the activities of the field of religious enlightenment" № PD-5416. According to him, the public charity fund "Vaqf" was established. This fund is responsible for the preservation, repair, beautification of historical and architectural shrines in our country, mosques, shrine staff, imam-khatibs, imam-deputies, mutawallis, muezzins, material and social support, salaries, religious enlightenment of our ancestors who made a great contribution to the development of Islam. The task was set to publish his works, to further increase the prestige of the shrines and shrines in the Muslim world in our country, to create conditions for the attraction of local and foreign pilgrims to the shrines. At present, 189 shrines and shrines across the country are attached to the charity foundation "Vaqf" on the basis of a contract of free use.

\section{CONCLUSION}

In the Middle Ages, sheikhs and servants worked in the shrines associated with the names of mystical scholars in Movarounnahr, and waqf property was allocated for the shrine and its worshipers. Pilgrims were provided with accommodation, meals and all conditions were created for them. Today, the life of great people buried in the shrine, the study of the history of the shrine, its transmission to the younger generation as our material and spiritual heritage, material and social support of employees of the shrine, raising the status of shrines in the Muslim world, beautification of shrines, One of the most important tasks before us is to create conditions for pilgrims and attract local and foreign pilgrims, to develop pilgrimage tourism.

\section{REFERENCES}

1. Abdulaxatov N. Azimov V. Altiyarik shrines. - T .: Sharq, 2005. 
2. Al-Jazari Muhammad Nurullah Saydo. Secrets of imagination. - $\mathrm{T}$.: Movarounnahr, 2000.

3. Amir Temur. Traps. - T .: Ekstremumpress, 2016.

4. Arshavskaya V.A, Rtveladze E.V, Hakimov Z.A. Medieval monuments of Surkhandarya. - T .: G.Gulyam, 1982.

5. Ibrohimov N. Ibn Batuta and his journey to Central Asia. - T .: Sharq bayozi, 1993.

6. Islamic encyclopedia. - T : National Encyclopedia of Uzbekistan, 2017.

7. Karmysheva B.X. O musulmanskom dukhovenstve $v$ selskix rayonax Buxaraskogo xanstva $\mathrm{v}$ konche XIXnachale $X X$ veka // Dukhovenstvo i politicheskaya jizn na Blijnem i Srednom Vostoke $v$ period feodolizma - M .: Nauka, 1985.

8. Osman Turor. History of Sufism. - $\mathrm{T}$.: Istiqlol, 1999.

9. Annotated dictionary of the Uzbek language. - T .: Fan, 1967.

10. Nurmatovna, D. S. (2020, October). Representatives of the" Khojagon" direction of the Naqshbandi sect. In Archive of Conferences (Vol. 7, No. 1, pp. 8-11).

11. Djuraeva, S. (2019). ZORAASTRISM AND ZOOLATRIC VIEWS AT THE MONUMENT JARQOTAN WHICH SITUATES AT THE SOUTH UZBEKISTAN. Theoretical \& Applied Science, (9), 166-168.

12. Djuraeva, S. (2019). SACRED PLACES IN SURKHAN OASIS AND POPULATION'S RELIGIOUS LIFE. Theoretical \& Applied Science, (7), 125-130.

13. Nurmatovna, D. S. (2020, October). Representatives of the" Khojagon" direction of the Naqshbandi sect. In Archive of Conferences (Vol. 7, No. 1, pp. 8-11).

14. Omonov, Q., \& Karimov, N. (2020). Importance of Ancestoral Heritage. The American Journal of Social Science and Education Innovations, 2(09), 196202.

15. Karimov, N. R. (2020). A True Successor of Great Central Asian Scholars. Journal «Bulletin Social-Economic and Humanitarian Research,(7), 62-69.

16. Djuraeva, S. (2020). THE ROLE OF SPIRITUAL AND MATERIAL HERITAGE OF SURKHANDARYA REGION IN THE DEVELOPMENT OF TOURISM. Solid State Technology, 63(6), 290-296.

17. Kariev, A., \& Aminov, H. (2020). New information about Imam al-Zarnūjī and his work "Ta'līm al-Muta'allim". Solid State Technology, 63(6), 2372-2387.

18. Kurbanazarova N. Sh. (2020). Linguistic Study of some Uzbek Ethnographisms Expressing Wedding Ceremonies. International Journal of Psychosocial Rehabilitation, No.5, Pp. 3735-3740 